\title{
The system of crop intensification: reports from the field on improving agricultural production, food security, and resilience to climate change for multiple crops
}

\author{
Binju Abraham ${ }^{1}$, Hailu Araya ${ }^{2}$, Tareke Berhe ${ }^{3}$, Sue Edwards², Biksham Gujja ${ }^{4}$, Ram Bahadur Khadka ${ }^{5}$, Yang S Koma ${ }^{6}$, \\ Debashish Sen ${ }^{7}$, Asif Sharif $^{8}$, Erika Styger ${ }^{9}$, Norman Uphoff ${ }^{9 *}$ and Anil Verma ${ }^{10}$
}

\begin{abstract}
In the past half dozen years, farmers and professionals working with them in several Asian and African countries have begun adapting and extrapolating what they have learned from and about the system of rice intensification (SRI) to a range of other crops - finger millet, wheat, sugarcane, tef, oilseeds such as mustard, legumes such as soya and kidney beans, and various vegetables - in what is being called the system of crop intensification (SCI). As with rice, the principles of early and healthy plant establishment, reducing competition between plants, increased soil organic matter, active soil aeration, and the careful application of water are proving able to raise the productivity and profitability of differently-managed crops. Recent reports from the World Bank in India and the Agricultural Transformation Agency in Ethiopia show such changes in crop management improving food security and being scaled up with hundreds of thousands of farmers.

This review article reports on the productivity and other impacts being observed for many different crops in half a dozen countries for increasing food crop yields with lower cost and input requirements as well as more resilience to adverse effects of climate change. It also reports on mechanization innovations that reduce labor requirements for these methods.
\end{abstract}

Keywords: Agricultural mechanization, Agroecology, Finger millet, Integrated farming systems, Sustainable intensification, System of crop intensification, System of rice intensification, Tef, Wheat

\section{The need for sustainable intensification of agricultural production}

Although varying terminologies are being used by different organizations, there is considerable agreement that agricultural sectors around the world need to pursue modified strategies for 'sustainable intensification' if global food security requirements are to be met throughout this century [1-6]. A common denominator for these recommendations is their divergence from the kinds of agricultural intensification that has been prevalent over the past 50 years.

\footnotetext{
*Correspondence: ntu1@cornell.edu

${ }^{9}$ SRI International Network and Resources Center (SRI-Rice), Cornell University, Ithaca, NY, USA

Full list of author information is available at the end of the article
}

Technologies for modern agriculture particularly associated with the Green Revolution have enabled farmers with access to sufficient land, machinery, and purchased inputs to cultivate ever-larger areas, raising production by relying on improved crop varieties and utilizing more water, capital investment, fossil-fuel energy, and agrochemicals. Employing more inputs to obtain greater output has improved upon the previous more extensive strategies of production that were characterized by both low inputs and low outputs. However, it has also become associated with rising economic and environmental costs for both farmers and ecosystems [7].

Intensification that depends essentially on greater use of external inputs is not the only kind of intensification available. There are other approaches to intensification to be considered under the rubric of agroecology [8-10]. 
This seeks to make the most productive use possible of available natural resources including the species and genetic biodiversity found in nature. Particularly as land and water resources become less abundant (and often of lower quality) relative to the human populations that depend on them, such resource scarcity places a greater premium upon improving the management of all the natural resources that are available.

\section{The system of crop intensification}

In recent years, something called the system of crop intensification (SCI) has emerged in a number of Asian and African countries, raising the productivity of the land, water, seed, labor, and capital resources that farmers invest can for growing a wide range of crops [11-13]. As noted below, this emergence is gaining recognition from major institutions such as the Ethiopian government's Agricultural Transformation Agency [14] and the World Bank [15,16].

The ideas and practices that have given rise to $\mathrm{SCI}$ have derived from farmers' and others' experience with the system of rice intensification (SRI) [17-19]. The principles constituting both SCI and SRI, based on demonstrated agronomic theory and practice, are shared with other agroecological domains of innovation such as agroforestry, conservation agriculture, integrated pest management, and integrated range and livestock management.

The common elements involved in SCI crop management, extrapolated by farmers and others from what has been learned from their SRI experience, can be summarized as:

- Establishment of healthy plants both early and attentively, taking care to conserve and nurture their potential for root system growth and for associated shoot growth;

- Significant reductions in crop density, transplanting or sowing individual plants with wider spacing between them, giving each plant more room to grow both above and below ground;

- Enrichment of the soil with organic matter, and keeping the soil well-aerated to support the better growth of roots and of beneficial soil biota;

- Application of water in ways that favor plant-root and soil-microbial growth, avoiding hypoxic soil conditions that adversely affect both roots and aerobic soil organisms.

The careful transplanting of young rice seedlings, a key practice for SRI methodology, has been found to have strong beneficial effects on some other crops such as finger millet, mustard, and tef, but not for all. Directseeding in conjunction with the other practices can be part of SCI, reducing labor requirements. Or with some crops like wheat it is simply more successful. Careful crop establishment is an essential part of agroecological management, whether for SRI or SCI.

Practices that apply these four principles are able to raise substantially the productivity and profitability of more 'intensively' managed crops. Improved production methods that are grouped and extended under the rubric of SCI are being scaled up in a significant way as seen in India and Ethiopia:

- The World Bank has documented large productivity and profitability gains for food-insecure households under one of its projects in Bihar state. As of June 2012, it reports, 348,759 farmers were using SCI methods on over 50,000 ha. It summarized their yield increases as $86 \%$ for rice, $72 \%$ for wheat, $56 \%$ for pulses, $50 \%$ for oilseeds, and $20 \%$ for vegetables. The profitability increases for these different crops were calculated, respectively, as averaging 250\%, 86\% $67 \%, 93 \%$, and $47 \%$ [15].

- Ethiopia's Agricultural Transformation Agency is applying, evaluating and extending SCI concepts and practices to raise production of that country's main staple grain, tef. What is referred to as the system of tef intensification (STI) is being promoted and assessed in two versions. In the 2012-13 season, 160,000 Ethiopian farmers who participated in on-farm trials with the less-intensive, direct-seeded version got an average yield increase of 70\%, while another 7,000 farmers who used the recommended, more-intensive methods that involved transplanting had yield increases of $200 \%$ to $300 \%$, with $50 \%$ to $90 \%$ reductions in seed [14].

This review article reports on SCI results being seen already across a range of countries - India, Ethiopia, Nepal, Mali, Cambodia, and Pakistan - for a wide variety of crops. The management methods presented range from highly labor-intensive to rather capital-intensive, showing that the new systems of cultivation are not limited by scale any more than by climatic and soil conditions. Where more labor is required, the returns to labor are significantly increased, as well as to land, water, and capital.

New opportunities are thus emerging for raising agricultural production in ways that can directly reduce food insecurity for several billion people and that do this in environmentally-friendly ways that enable crops to withstand biotic and abiotic stresses which are becoming more severe with climate change $[20,21]$. That SCI gains in productivity are being achieved in places where food insecurity is greatest - like Ethiopia, Bihar state of India, the hills of Nepal, and the Timbuktu region in Mali - 
makes the yield enhancements being achieved all the more noteworthy for improving people's lives and livelihoods.

These innovations are being driven mostly by farmer interests and initiatives, supported by professionals from non-governmental organizations, government agencies and research institutions, universities, and the private sector, all represented by the contributors to this review. More detail and more data are provided in a monograph prepared by the authors based on their experiences and observations of varied crops in their respective countries [22].

That most of the information is currently still in nonpublished form does not make it untrue. Web links are provided for most of the unpublished reports so that readers can evaluate these for themselves. The authors are not proposing that the methods reported here be adopted on a mass scale without further investigation. We believe, rather, that the methods reported deserve further, systematic study and serious efforts at scientific explanation, seeking to promote improved food security especially among those resource-limited populations that labor under the severe challenges of climate change.

\section{Crop adaptations and results}

We are reviewing here what is being done and seen on farmers' fields rather than on experiment stations because these innovations have been mostly developed empirically on the ground. Few researchers have been involved in this effort with scientific evaluations, but this is now changing $[23,24]$. In this review, observed and measured outcomes are communicated as accurately as possible from on-farm situations. All comparisons of SCI results are with farmers' present practices. While some readers might question the reported SCI yields as absolute measures, similar reservations would not apply to the reported relative measures, i.e., ratios of yield, since the same methods of measurement were used for both sets of results.

Most of the impacts being observed and reported are large and consistent enough that the usual statistical tests of significance are of less relevance than when there are small differences that could be just measurement artifacts or chance occurrences are being reported. The photographic evidence that supplements the text reinforces the proposition that something of agricultural significance is occurring, to be investigated more extensively and systematically.

We review in some detail three major food crops important for food security in Asia and parts of Africa - finger millet, wheat, and tef - because there is most information and data available on the effects of SCI management for these cereals. The effects of SCI for various other crops are discussed only briefly here, with information on these crops reported in [22].

\section{Finger millet (Eleusine coracana)}

Finger millet is the staple food for millions of poor households in India, Nepal, Sri Lanka, and parts of Eastern Africa. Its high nutritional content has made it a food traditionally fed to pregnant and lactating women and often used as a weaning food for babies.

\section{India}

Farmers in Haveri district in the southern state of Karnataka over several decades developed their own set of novel practices for finger millet that are remarkably close to SRI management [25]. Conventional crop management, which starts with broadcasting finger millet seed on a tilled field, gives yields between 1.25 to 2 tonnes/ha. With good irrigation and fertilizer applications, millet yields in the district can reach 3.75 tonnes.

With their Guli Vidhana methodology, farmers start by making a square grid of shallow furrows on their fields using a simple ox-drawn plow. The grooves in the soil, made in parallel and perpendicular directions, are widely spaced, $45 \times 45 \mathrm{~cm}$. At each intersection of the grid, two young, 12-day-old seedlings are transplanted, putting a handful of compost or manure around the roots to give the young plants a good growing environment.

While the plants are still between 15 and 45 days after transplanting, farmers pull a light board across the field in several different directions. The board's bending the young plants over imposes some moderate trauma that promotes the growth of more roots and tillers from their crowns' meristematic tissue. Concurrently, farmers loosen the soil between the plants several times with another ox-drawn implement that cuts the roots of any weeds growing between the millet plants about 3 to $5 \mathrm{~cm}$ depth below the soil surface (Figure 1). This active soil aeration along with organic matter supplementation enables the millet plants to have 40 to 80 tillers and to give yields of 3.75 to 5 tonnes/ha, even up to 6.25 tonnes, which is two to three times the usual yield in the district.

In the eastern state of Jharkand, Indian farmers after they were introduced to SRI methods for growing rice by the NGO PRADAN began experimenting with SRI methods for their rainfed finger millet crop in 2005, calling this the System of Finger Millet Intensification (SFMI). Usual yields there with traditional broadcast practices are around 1 tonne/ha. By starting their crop with young transplanted seedlings, widely spaced, and with active soil, water and nutrient management, SFMI yields rose to 3 or more tonnes/ha. While the intensified management increases farmers' costs of production by about 25\%, the higher yields that they get reduce their costs of production from Rs 34.00 per $\mathrm{kg}$ of grain to Rs 13.50 per $\mathrm{kg}$, a $60 \%$ reduction that makes SFMI very profitable [26]. 


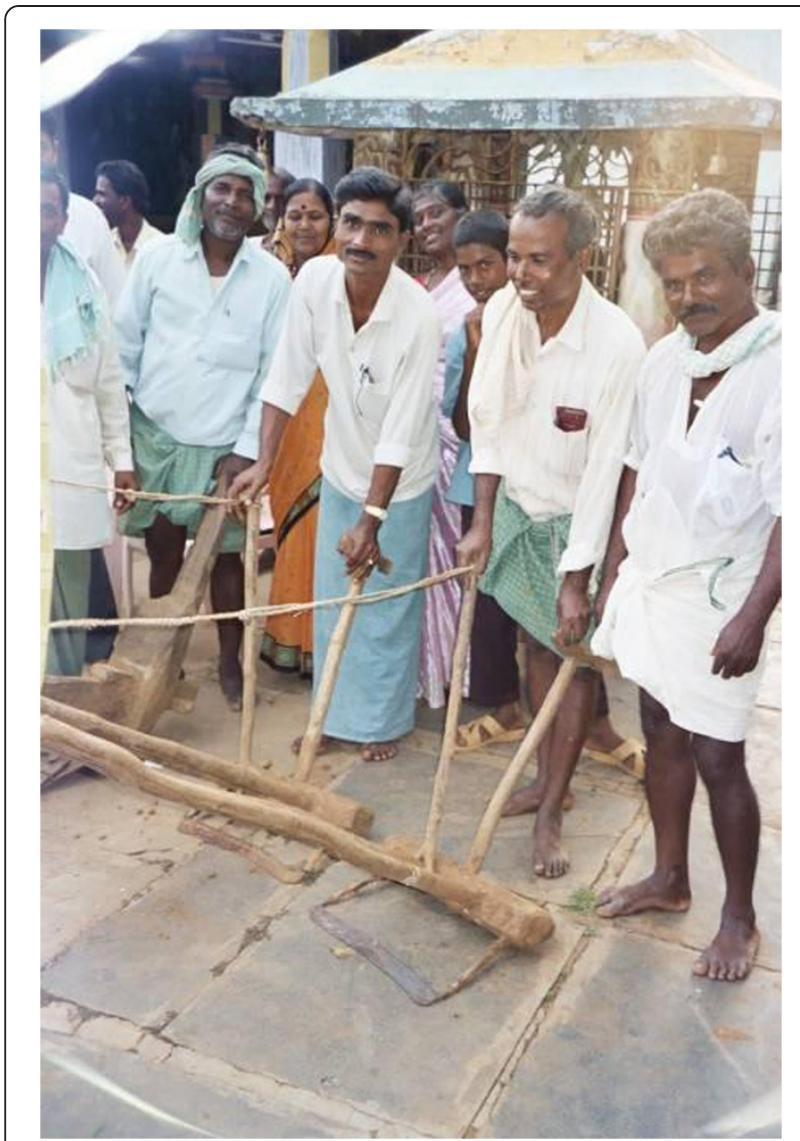

Figure 1 Demonstration of the yedekunte implement used by farmers in Karnataka state of India. The implement cuts weed roots below the soil surface between rows, thereby also aerating the top layer of soil (Norman Uphoff).

In northern India, the People's Science Institute (PSI) undertook the first trials of another version of SFMI in 2008. Forty-three farmers in the Himalayan state of Uttarakhand tried these methods on a small area of 0.8 ha. Their results showed a $60 \%$ increase in grain yield, moving from an average of 1.5 tonnes/ha to 2.4 tonnes/ha. By 2012, more than 1,000 farmers were using locally-adapted SFMI methods, spacing their plants $20 \times 20 \mathrm{~cm}$ apart and establishing them either by direct-seeding or by transplanting young seedlings just 15 to 20 days old.

Such modified practices induce more productive millet phenotypes as seen in Figure 2. This result can be explained at least in part by the enhanced root growth on millet plants when seedlings are transplanted at a young age. This was documented by university researchers in Andhra Pradesh state before any farmer experiments started in India (Figure 3).

\section{Ethiopia}

Similar crop responses to SCI management have been observed in Tigray province. The first farmer

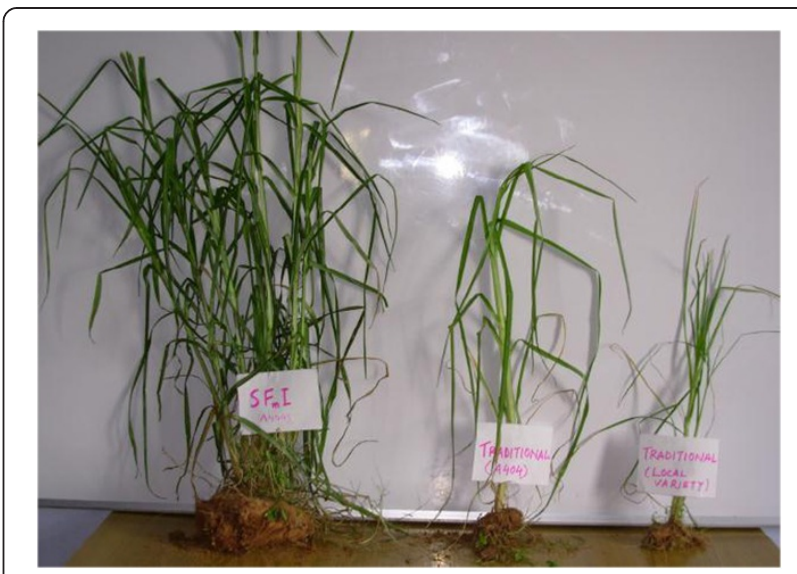

Figure $\mathbf{2}$ Comparison of typical finger millet plants grown with different management practices. The plant on left is an improved variety (A404) grown with farmers' SFMl practices. The plant in center is the same improved variety with conventional broadcast management, while the plant on right is a local variety grown with the same conventional management (Binju Abraham).

who transplanted finger millet seedlings there was an elderly woman who obtained a yield equivalent to 7.8 tonnes/ha in 2003, compared to usual millet yields of 1.4 tonnes/ha from fields established by broadcasting, or 2.8 tonnes/ha with generous use of compost [12]. As discussed below, farmers in Ethiopia have come to call this methodology 'planting with space' and are applying it also to other crops.

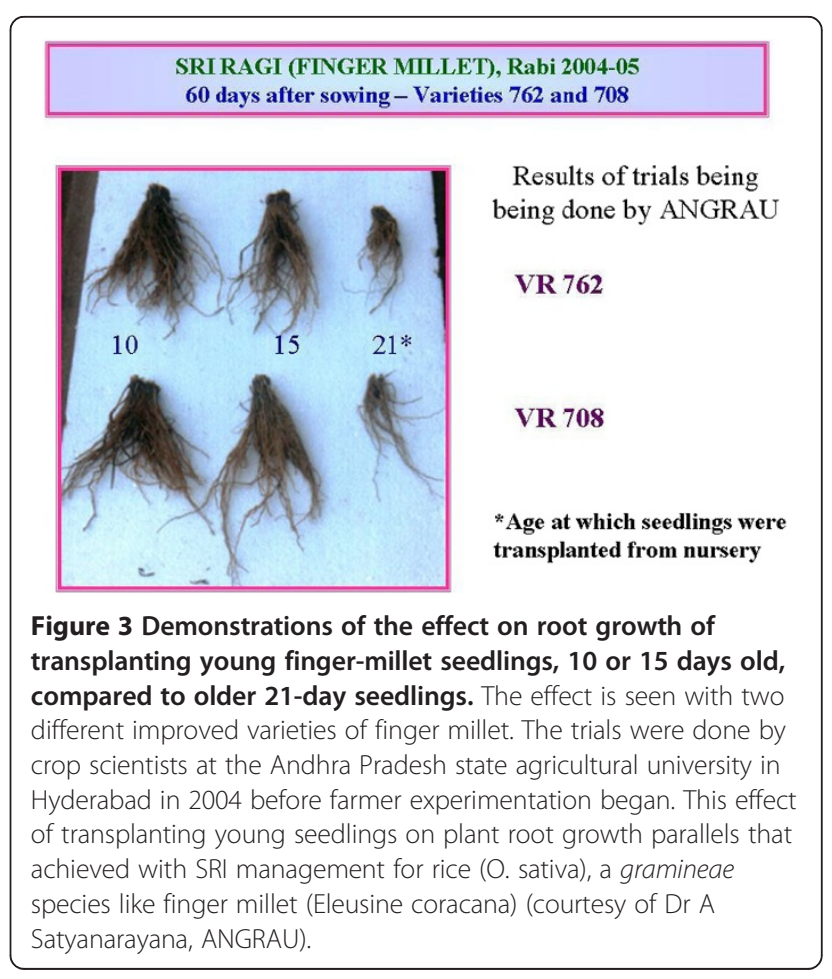


These methods have become standard practice among farmers in the Axum area of Tigray. Yields now average 3.5 to 4 tonnes/ha, similar to SFMI yields in Bihar and higher than those reported from northern India. Some Tigrayan farmers have even obtained $>6$ tonnes/ha when the rainy season is long enough, continuing from July into mid-September. These farmers are all making and using compost which they apply to the soil when they transplant their seedlings.

\section{Wheat (Triticum)}

The extension of SRI practices to wheat was fairly quickly seized upon by farmers and researchers in India, Mali, and Nepal once they began seeing SRI effects with rice.

\section{India}

What is now called the System of Wheat Intensification (SWI) was first tested in northern India in 2006 by farmers working with the People's Science Institute (PSI). First-year trials near Dehradun, using several varieties, showed average increases of $18 \%$ to $67 \%$ in grain yield and $9 \%$ to $27 \%$ higher straw yields (important for subsistence farmers as fodder) compared with the yields that farmers usually attained with conventional broadcast methods for crop establishment.

Impressed with these results, PSI began promoting SWI in the states of Uttarakhand and Himachal Pradesh [27]. Starting with 50 farmers in 2007, the number of smallholders using SWI methods expanded to more than 12,000 by the 2011-2012 winter season. Average increases in grain yields from irrigated SWI reached $80 \%$ to $100 \%$ over usual farmers' practice, while in unirrigated rainfed cultivation the yields with SWI methods were increased by $60 \%$ to $80 \%$. Despite the need for higher labor investments in sowing and weeding operations, farmers found the ratio of benefits-to-costs with SWI management to be favorable due to the higher yields of grain and straw.

Encouraged by good farmer response and results in these two states, PSI has been promoting SWI within a wider region of northern India since 2010, including several districts in Uttar Pradesh and Madhya Pradesh states. Households there suffer from low food productivity, having little irrigated area and frequent rainfall failures. Starting with 590 farmers in this expanded area in 2010, the number of SWI farmers rose to 1,015 the next year, and by 2012, this number had grown to 4,350 . More details on PSI experience with SWI introduction are given in [28].

The most dramatic results and the most rapid growth in use of SWI have been in the state of Bihar where landholdings are very small with an average of only 0.3 ha. At the initiative of the NGO PRADAN, 278 farmers in Gaya and Nalanda districts, mostly women, tried out the new methods in the 2008-09 season. Their yields averaged 3.6 tonnes/ha compared with 1.6 tonnes/ ha when using usual practices (Figure 4). The next year, 15,808 farmers using SWI methods had yields averaging 4.6 tonnes/ha. Two years later, the SWI area had expanded to 183,063 hectares with support from the Bihar Rural Livelihood Promotion Society (JEEVIKA), which channeled World Bank/IDA funding for NGOs' and state extension activities [15]. Average SWI yields in 2012 were 5.1 tonnes/ha according to Bihar Department of Agriculture calculations.

Intensified management for SWI requires more labor and more organic matter inputs, so farmers' costs of production per hectare are figured to have risen by about $60 \%$. Still, with yields more than doubled, farmers' net income per hectare has increased by $150 \%$, from Rs 17,460 to Rs 43,952, as costs of production per $\mathrm{kg}$ of wheat decline by $28 \%$. Experience of Bihar farmers working with PRADAN, including economic evaluation, is summarized in [29].

The Aga Khan Rural Support Programme in India has also been introducing SWI in Bihar state with different but still favorable results. It reported SWI yield increases less than other parts of India, just 32\%, with farmers averaging 3.48 tonnes/ha instead of 2.63 tonnes/ha with usual practices. However, farmers' costs of production with this version of SWI declined by $2 \%$ per hectare rather than increasing. Accordingly, their cost per $\mathrm{kg}$ of grain produced was Rs 8.17 with this less intensified version of SWI compared to Rs 11.05 using standard practices. This SWI makes wheat cultivation more profitable, as standard practices produce little net income for farmers, just Rs 1,802 per ha. On the other hand, with

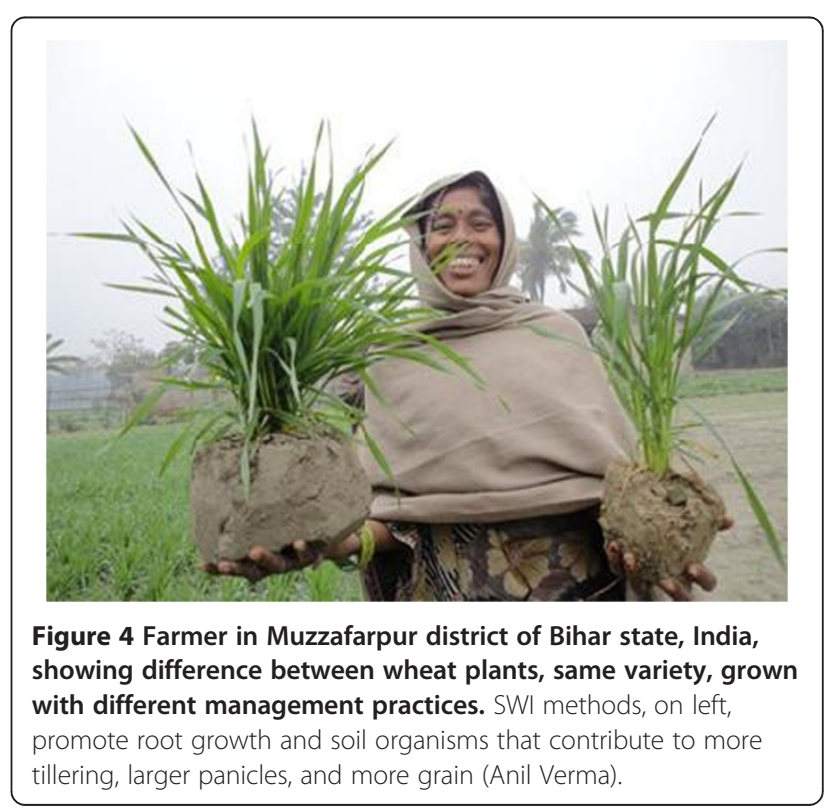


SWI practices, farmers' net income per ha was calculated to be Rs 18,265 [30].

\section{Mali}

The international NGO Africare introduced SRI methods for irrigated rice into the Timbuktu region in 2007. During an evaluation of SRI results the next year, when 60 farmers had grown rice on side-by-side comparison plots using SRI and conventional methods [31,32], the idea was put forward by farmers to apply the same principles to wheat, their winter crop.

Three farmers from three villages volunteered to do SWI trials, using the same methods as SRI. But simply imitating SRI was not very successful; the mortality of transplanted seedlings was $9 \%$ to $22 \%$, and $25 \times 25 \mathrm{~cm}$ spacing was too wide for plants to utilize all the arable area. Transplanted SWI produced 29\% less grain than the control plots (1.4 tonnes/ha vs. 1.97 tonnes/ha). Direct-seeded SWI, on the other hand, with widelyspaced individual plants showed a 13\% yield increase, producing 2.22 tonnes/ha. Farmers were pleased with their $94 \%$ reduction in seed requirements with this method of SWI (10 kg/ha vs. $170 \mathrm{~kg} / \mathrm{ha}$ ); also they found their labor investment reduced by $40 \%$, and their need for irrigation water was $30 \%$ less [33]. Thus, farmer interest in this innovation was aroused.

In the next season, 2009/2010, Africare undertook systematic SWI trials comparing different spacing and seeding techniques [34]. While the highest yield (5.4 tonnes/ ha) was with spacing of $15 \times 15 \mathrm{~cm}$, closer than usual SCI, all of the treatments that used single plants/hill gave yields above 4 tonnes/ha with spacing ranging from $10 \times 10 \mathrm{~cm}$ to $20 \times 20 \mathrm{~cm}$. Row-planting with $20 \mathrm{~cm}$ distance between rows also gave over 4 tonnes/ha (Figure 5), and all these yields were higher than the 2.2 tonnes/ha from the control lots that were broadcast with farmers' methods (Styger, Ibrahim, and Diaty, unpublished).

In a third season, SWI trials continued among farmers, even though Africare had no funding to support their testing; the experience of 21 farmers was monitored. Their average SWI yields were 5.45 tonnes/ha, compared to 1.96 tonnes/ha from conventional practice (Styger and Ibrahim, unpublished). The next year, when there was drought and irrigation water was limited, Africare was able to monitor 142 farmers using SWI methods in 13 villages. Despite the adverse conditions, SWI yields averaged 3.2 tonnes/ha compared to 0.94 tonnes/ha on conventionallygrown plots (Styger and Ibrahim, unpublished).

Farmers when interviewed indicated that applying SWI on a larger scale is constrained by the lack of a good implement for direct-seeding, as well as by difficulties in soil preparation and manure transportation, and by shortages of timely, small amounts of irrigation water. These factors limit the area of land that can be planted with SWI methods at present. Remedying these constraints could greatly enhance wheat production in Mali in the future.

\section{Nepal}

A majority of Nepalese farmers are smallholders whose landholdings are below 0.5 ha and whose wheat yields usually average around 1.2 tonnes/ha. For the last half decade, farmers have faced severe scarcity of fertilizers for their main wheat cropping season, and rainfall in the winter season has been erratic. These factors, plus very low seed replacement rates in the hill and mountain areas, have contributed to the extremely low productivity of wheat in Nepal.

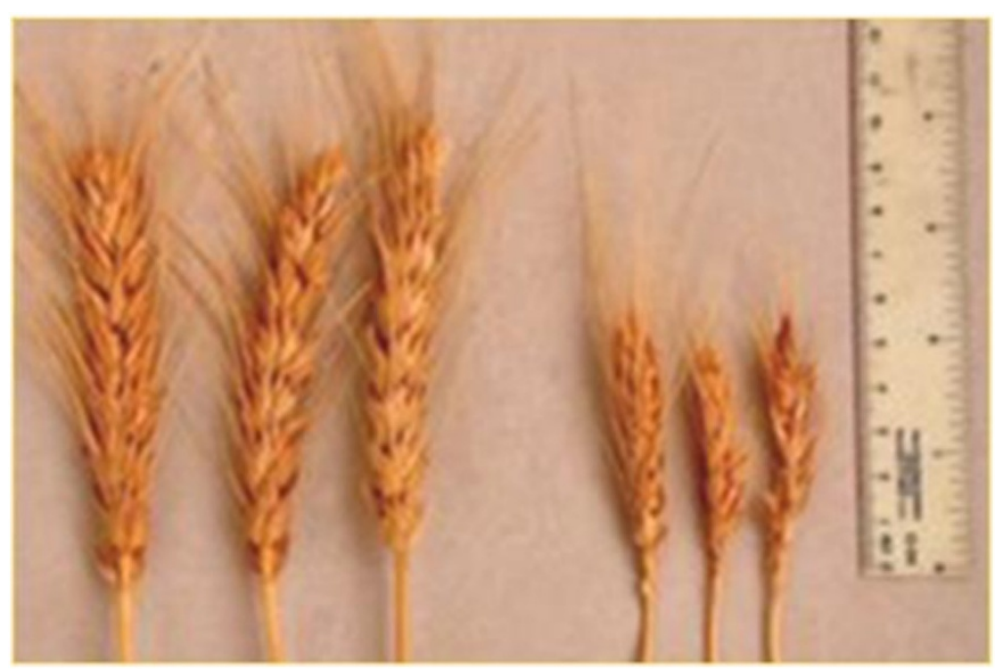

Figure 5 Comparison of SWI panicles on left and conventionally-grown wheat panicles on right. From 2009-2010 season trials in Timbuktu region of Mali (Erika Styger). 
Under an EU-funded Food Facility Program implemented in the Far Western Region by FAO and local NGOs, SWI concepts and practices were introduced to smallholding farmers in 2009, using direct-seeding rather than transplanting because the former performed better under local conditions. It was found that 'sowing with proper plant density allows for sufficient aeration, moisture, sunlight and nutrient availability, leading to proper root system development from the early stage of crop growth' [35]. Such management was seen to lead to more productive phenotypes.

Comparison trials in the 201011 season at 16 locations in three districts (Dadeldhura, Baitadi, and Kailali) showed that SWI methods with seed-priming and linesowing, using a recommended improved variety (WK1204) and reducing the seed rate by $>80 \%$, gave small farmers $91 \%$ more yield than from local practices with this same variety (6.5 vs. 3.4 tonnes/ha). The number of grains per panicle was 75 vs. 44, and grain weight (grams per 1000 grains) was 29\% higher with SWI (Figure 6). Although farmers' expenditures with SWI's more intensive crop management were 58\% higher per ha (Rs 5,010 vs. Rs 3,170), farmers' net income was more than doubled, rising from Rs 4,830/ha to Rs 9,830/ha.

In the 2011-12 season, farmer field school experiments conducted in Sindhuli district with similarly modified SWI practices also showed better yield and economic returns. Pre-germinated seed of Bhirkuti variety sown at $20 \times 20 \mathrm{~cm}$ spacing gave $54 \%$ more yield than the available best practices under similar conditions of irrigation and fertilization: 6.5 tonnes/ha from SWI methods compared to 3.7 tonnes/ha with conventional broadcasting, and 5 tonnes/ha with row sowing [36].

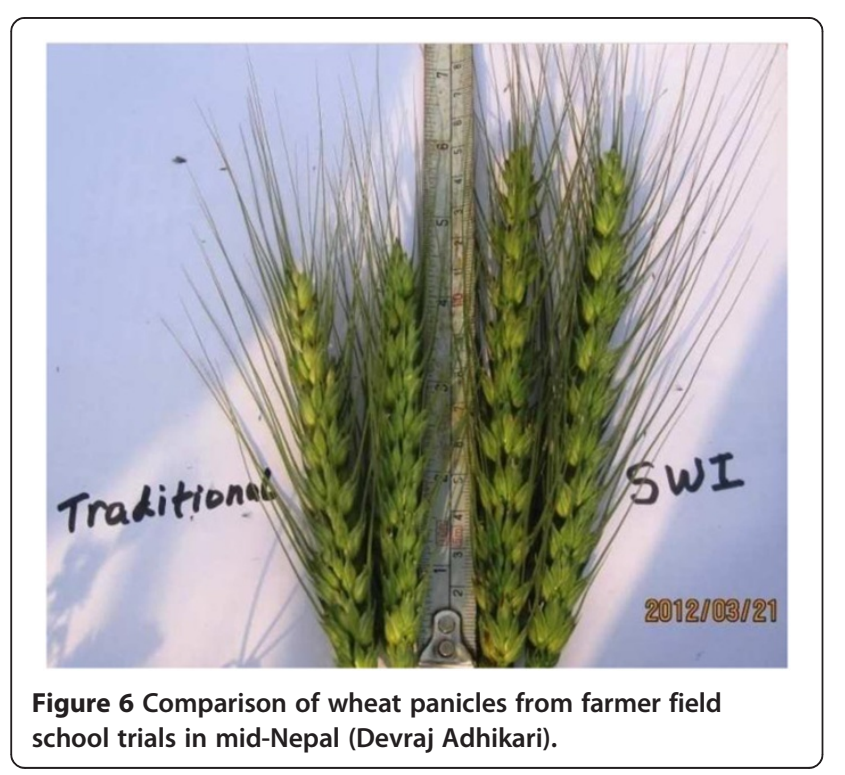

With SWI methods, farmers find their seed requirements reduced by $80 \%$ (20 kg/ha compared with $120 \mathrm{~kg}$ for usual practice). This means that their limited supply of improved seed can be used on four times more cultivated area, and purchasing fertilizer is less necessary if biomass-based fertilizers can be procured locally.

Using improved seed with SWI crop management techniques will enable an average household with six members in the Far West, a region known for its extreme poverty, to achieve an additional 6 months of food security each year [35]. Ethiopian experience with other versions of SWI is discussed below under Planting with Space. In China, efforts have begun to combine SWI with SRI in integrated farming systems $[37,38]$.

\section{Tef (Eragrostis tef) \\ Ethiopia}

This crop, the preferred cereal in this large food-deficit country, is grown from tiny seeds (2,500 per gram) that are traditionally broadcast on repeatedly ploughed soil. Despite much labor invested, mostly by women and children, yields are usually only about 1 tonne/ha. Adaptation of SRI methods to tef cultivation was started in the 2008-09 season under the direction of Dr Tareke Berhe, at the time with the Sasakawa-Global 2000 program but now director of the Tef Value Chain Program under the government's Agricultural Transformation Agency (ATA).

By transplanting young, 20-day-old tef seedlings at $20 \times 20 \mathrm{~cm}$ spacing with application of organic and inorganic soil nutrients, tef yields could be raised to 3 to 5 tonnes/ha. Further, with micronutrient soil amendments ( $\mathrm{Zn}, \mathrm{S}, \mathrm{Mn}$, and $\mathrm{Mg}$ ), these improved yields could be almost doubled again, in what Tareke called STI, the system of tef intensification.

In 2010, in collaboration with the Institute for Sustainable Development (ISD) which had obtained some funding from Oxfam America for SCI development, Tareke conducted demonstration trials at two major centers for agricultural research in Ethiopia. Good results there gained acceptance for these new practices from other tef scientists and government decision-makers, and ATA began more systematic evaluations and demonstrations [24].

In the 2011-12 season, 1,400 farmers who used STI methods averaged 2.7 tonnes/ha, with yields as high as 5 tonnes/ha. Then in the 2012-13 season, 7,000 farmers used STI methods in expanded trials with transplanted seedlings, while another 160,000 farmers applied less intensified methods, doing direct-seeding in rows instead of transplanting. This kind of 'STI-lite' raised tef yields on a large scale from 1.2 tonnes/ha to 2.1 tonnes/ha, based on results gathered from 15,800 farmers and 1,100 farmer training centers [14]. With such results, the Ethiopian government has scaled up the area for STI 
management to over 1 million ha in the 2013-14 season, and the aim of having 2.5 million ha for STI the following year.

Direct-seeded STI follows SRI principles, including wider spacing $(20 \mathrm{~cm})$ between rows and enhancement of soil organic matter with compost, supplemented with some urea and DAP. These 'STI-lite' practices which improve the balance of air and moisture in the soil require less labor for sowing and weeding than does 'full STI' management. More intensive management which starts with transplanting young tef seedlings and puts more emphasis on organic soil fertilization can give farmers even better results (Figure 7), but choice of methods is left to farmers.

Like other crops, the tef genome is highly responsive to management practices that do not crowd the plants together and that improve soil conditions. When individual tef plants are given ample space, their leaves are longer and wider; their darker green color indicates that the plants' photosynthetic efficiency, usually low, is enhanced by their altered growing conditions. Tef plants given wider spacing exhibit much larger and longer root systems. These in turn support larger, taller canopies that resist lodging, a major constraint with conventionally-grown tef.

For countless generations, this crop has been grown by broadcasting with high plant densities. STI, in contrast,

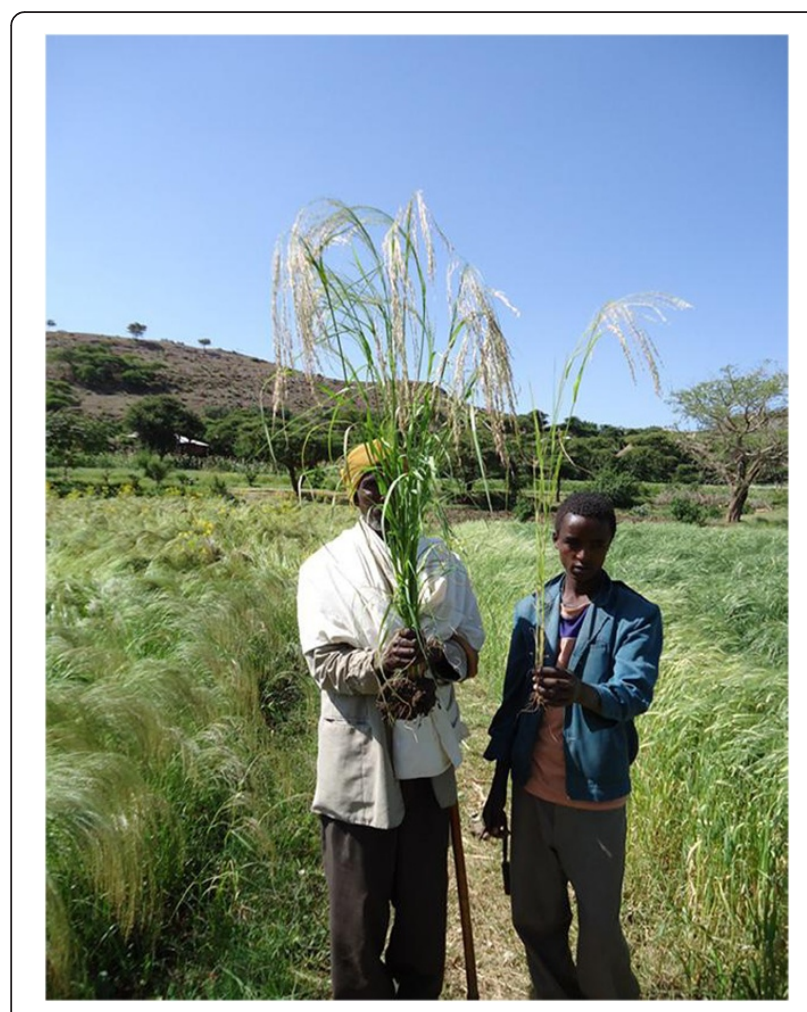

Figure 7 Comparison of transplanted STI plant on left, and broadcasted tef plant on right, same variety (Hailu Araya). reduces plant density by as much as $90 \%$, using 9 to 15 million seeds/ha instead of 90 to 150 million/ha. By transplanting tef seedlings and making other changes in crop management, the yields of tef grain and straw can be tripled or more (Figure 8).

\section{Other crops}

In a review article like this, it is not possible to discuss all of the SCI experience to date, such as with sugarcane [39,40], mustard (Brassica rapa) [41], maize (Zea mays), various legumes such as pigeon pea (Cajanus cajan, also known as red gram), mung bean (Vigna radiata, or green gram), lentils (Lens culinaris, or black gram), broad bean (Vicia faba), soya bean (Glysine max), kidney beans (Phaseolus vulgaris), and peas (Pisum sativum), as well as a number of vegetables including tomatoes, chilies, eggplant (aubergine or brinjal), and even a root crop, turmeric [42], and castor bean in the spurge family [43]. Specific information on these crops is provided in [22].

\section{Planting with space}

As noted above, ISD in Ethiopia works with farmers who are dependent on rainfed production, having small parcels of land, from less than one-quarter to half a hectare each. They live and farm mostly in drought-prone areas of northern Tigray and South Wollo provinces, although some are in better-endowed areas near Addis Ababa. Following from farmer experimentation starting in 2003, discussed above, when finger millet was first established by transplanting seedlings, ISD has had little difficulty in getting support from farmers and local extension staff to adapt SRI/SCI ideas to other crops under the rubric of 'planting with space', a strategy that farmers have found easy to comprehend $[12,44]$.

For a number of crops, Ethiopian farmers are now either transplanting young seedlings or sowing seeds directly in rows, with wide spacing between the rows and

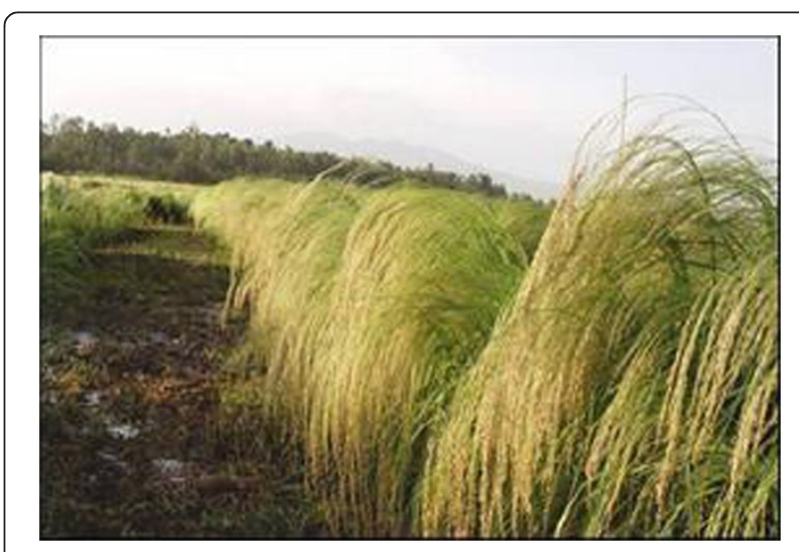

Figure 8 STI tef crop ready for harvest at Debre Zeit Research Station in Ethiopia (Tareke Berhe). 
between the plants in each row. Farmers make and use compost, which is now being promoted as part of the government's extension package in all crop-growing areas, either to be used alone or with small supplemental amounts of chemical fertilizer. Farmers control weeds by breaking up the topsoil with a fork or some other implement that also aerates the soil. The crops whose yields have been substantially improved this way include barley, durum wheat, maize, sorghum, tef, faba bean, and lentils. Optimizing the spacing of plants proves beneficial so long as the soil is well supplied with organic matter so that rainwater, dew and air can enter easily.

\section{Extension of agroecological ideas to different products and farming systems}

Where this process on innovation will end cannot be predicted. Growing numbers of farmers are gaining confidence in their ability to produce 'more from less' and to provide more adequately for their families' food security while enhancing the quality of their soil resources and buffering their crops against the temperature and precipitation stresses of climate change.

\section{Unusual crops}

There have been a number of unanticipated extrapolations and extensions of SRI ideas and methods to quite different kinds of agricultural production. Farmers who understood the principles underlying SRI management have adapted them, for example, to a root crop (turmeric), an entomological (insect) product (lac), and even to animal husbandry (chickens) [22]. Through experimentation, farmers have found that they could greatly increase their output from existing resources by managing these differently and better. Some of the changes made in their production practices are ones that few researchers would have been likely to imagine.

\section{Smallholder diversification}

While achieving greater productivity from individual crops or commodities is important for farming households, families depend for their wellbeing on their whole farming systems, not just on any one component of these systems. In Cambodia, farmers working with the NGO CEDAC have very small landholdings, on average about 0.66 ha.

With CEDAC encouragement, several thousand farmers have started capitalizing on the productivity gains that SRI management is bringing to their paddy fields by reorganizing, diversifying, and intensifying their rice-based farming systems. With their previous paddy yields now doubled or tripled, farmers can take $30 \%$ to $50 \%$ of their paddy land out of rice production, as they are able to meet or exceed their households' staple food needs by using SRI methods on their remaining rice area [45].
The first step for such diversification is constructing a pond, about $10 \times 15 \mathrm{~m}$ in area and 2 to $3 \mathrm{~m}$ deep, which can capture water during the rainy season and store it into the dry season. Fish, eels, frogs, and other plants and animals are raised in the pond and canals which provide water and liquid manure to make the rest of the farmed area more productive. A great variety of crops and livestock are grown on the non-paddy area: tomatoes, eggplants, watermelons, cucumbers, pumpkins; mung beans and other legumes; bananas, papayas, and other fruit trees; sugarcane, cassava, and maize in upland areas; as well as chickens, pigs, and/or rabbits.

The ponds and canals in the rice fields serve a number of functions. During the early monsoon, they help farmers drain excess water from their rice fields, so that young seedlings will not suffer from too-high water levels in the fields. During short dry periods within the monsoon, water from the pond can be used to irrigate the young rice plants so they withstand water stress. Frogs and fishes living in the ponds and canals help to control insects during the growing season.

During the late monsoon, when the rice plants start to flower, the frogs and fish move from the ponds into the rice fields, where they find plenty of food. During the grain-filling phase, the fields are kept flooded with just a few centimeters of water to ensure sufficient supply for producing full grains. When the crop is ripe, the fields are drained for easier harvesting of the rice, and fish and frogs can also be harvested at the same time, augmenting household income and food supply.

Details on cropping, land use, and investments made from the experience of five innovative but representative farmers are given in [45]. They have, on average, tripled their household incomes, with annual cash earnings rising from $\$ 200$ to $\$ 600$. The average capital investment required was only about $\$ 300$, made incrementally over several years with no borrowing needed.

Apart from these monetary gains, Cambodian farmers appreciate the diversification and enrichment of their household diets which this redesign of their farming systems makes possible. They also appreciate having multiple sources of income that bring in at least some cash income throughout the year. Household food security no longer depends just on their seasonal rice harvests with one or two surges of income during the year. This intensification also creates paid employment opportunities in rural areas that make migration to urban areas less necessary.

Farmers following agroecological management further report improvements in their soil and water quality, with less build-up of synthetic chemicals. Such a diversification based on farming system intensification will not meet the needs of all rural households; for example, it requires at least some access to irrigation or sufficient 
rainfall to fill ponds. But the productivity of rather small extents of land can be greatly enhanced by this kind of intensified agroecological management.

\section{Larger-scale, mechanized operations}

Agroecological innovations need not be limited to smallholder farming. In Pakistan's Punjab province, a large farmer who is also a businessman, inventor, and philanthropist has developed several machines that implement SRI principles in conjunction with conservation agriculture (CA) and organic soil improvement, aiming to build up soil fertility and to minimize external energy and agrochemical inputs over time [46].

Initially, SRI methods were adapted to produce rice on permanent raised beds formed by a specially-designed machine on a laser-leveled, 8-hectare 'test plot.' Irrigation/drainage ditches were formed in between the beds to establish furrow irrigation for reducing water applications. Mechanized transplanting, precise spacing of plants, precision applications of compost and some inorganic fertilizer, plus fully-mechanized weeding to aerate the topsoil between plants thoroughly, all contributed to a paddy yield of 12 tonnes/ha. This yield was produced with $70 \%$ reductions in both water and labor, compared to the usual amounts of water and labor utilized for growing rice in the region [46].

Now this technology is being adapted to many other crops. This mechanized farming system, following CA principles, including no tillage after the beds have been formed, rotates various crops with rice or with each other. These crops include wheat (with yield doubling to 7.3 tonnes/ha), carrots (tripled production), maize, cotton, sunflower, potatoes, tomatoes, and onions. Largescale mechanized cultivation on permanent raised beds together with furrow irrigation using siphons reduces both water requirements and energy costs. Following SRI principles is saving labor, cost, and water and building up soil fertility. These demonstrations indicate that SCI presents opportunities for large-scale farmers also to capitalize on the biological dynamics discussed here. Starting in 2013, USDA and USAID programs in Pakistan have sponsored farmer field days for potato production where SCI innovations are applied.

\section{Conclusions}

This review indicates that SCI is an evolving phenomenon, still a work in progress [47], not yet getting much attention in scientific journals. Some of the data reported here are from controlled, even replicated trials; but much systematic research remains to be done. Most of the data and reports cited here are available online, presented not as definitive results but as observations and measurements that should attract the interest of researchers as well as anyone concerned with improving agriculture and food security in the world.

The data reported here and summarized in annexes to [22] show considerable variability across crops and countries, but generally speaking, there has been more than a doubling of yields by using modified methods of crop management. Crop-wise, the typical yield increases range from $60 \%$ for sugarcane to $180 \%$ for wheat.

In economic terms, the per-hectare costs of production with such intensification go up on average by about $50 \%$. But with the increases in yield, the costs of production per unit of crop output decline, on average by $40 \%$ across the crops for which detailed cost and return data are available. Consequently, farmers' net income per hectare from these crops is usually considerably more than doubled.

While the data presented here are not complete or standardized enough for strong scientific conclusions, the patterns of yield and profitability improvement are dramatic and consistent enough to have attracted the attention of already millions of farmers and also of policy makers, particularly in Ethiopia and Bihar state of India $[14,15]$.

This information has been assembled to bring these opportunities to the attention of a wider audience that is concerned with improving agricultural production and food security, and one that also desires to conserve environmental resources and help farmers cope with increasing climatic stresses now and in the future.

Finding explanations for the evident improvements in soil/plant interaction and crop performance presents both challenges and opportunities to the scientific community. As no harm is seen from such modifications of crop management practices, their experimentation, demonstration, and adaptation represents an opportunity available for both farmers and the agencies and professionals working with them for raising farmers' yields and incomes in ways that are environmentally benign.

\section{Competing interests}

The authors declare that they have no competing interests, having no financial stake in any of the innovations reported. They have, of course, personal and professional interests in the success of such innovations for increasing farmers' agricultural production and households' food security.

\section{Authors' contributions}

The authors contributed written material, data, and pictures from their respective involvements with $\mathrm{SCl}$ in different countries. BA supported initiatives on SCl practices for finger millet and lac, building on PRADAN's SRI work with rice in Jharkhand state of India. HA and SE oversaw and facilitated work with farmers in several provinces in Ethiopia on finger millet, tef, and other crops 'planting with space'. TB undertook the first trials with SRI methods for tef in Ethiopia and continues to oversee a national government program on STI. BG supported the extension of SRI concepts and practices to sugarcane (SSI) in India after working with SRI as director of a WWF-ICRISAT dialogue project on food, water, and environment in Hyderabad. RBK worked with SWI for wheat as well as SRI for rice in the Far Western region of Nepal under an EU-funded food security project implemented by FAO. YSK introduced SRI for rice in Cambodia as director of CEDAC and then 
encouraged farmers to develop their own diversified-intensified farming systems in that country. DS has worked with farmers in northern India to adapt SRI ideas for wheat, finger millet, maize, legumes, and other crops through the People's Science Institute based in Dehradun. AS developed custom-made machinery as a private individual to reduce labor and save water while raising the yields first of rice and then wheat, legumes, cotton, sunflower, and other crops on raised beds with no tillage in the Punjab province of Pakistan. ES assisted farmers in the Timbuktu region of Mali on behalf of Africare to adapt SRI methods for wheat SWI. NU has visited and/or corresponded extensively with all the other contributors, consolidating their knowledge and experience into a monograph [22] and this review article. He has also made field visits in India to learn about the farmer-initiated finger-millet SCI known as Guli Vidhana in Karnataka, and SCl applications for turmeric in Tamil Nadu and lac in Jharkhand states, and in Cambodia to see farmer innovations with 'diversified intensification'. AV introduced SRI and then SWI in Bihar state of India, and then helped to extend applications of this experience to mustard, finger millet, legumes, and numerous vegetable crops. All authors read and approved the final manuscript.

\section{Acknowledgments}

The authors gratefully acknowledge the cooperation and the innovative efforts and ideas of countless persons, both farmers and institutional colleagues in our respective countries. We acknowledge the assistance of Dr Rena Perez for introduction of SSI for sugarcane into Cuba. Almost all of the work reported here has been 'bootstrapped' as part of ongoing development programs and activities, without any dedicated funding as with a conventional research project.

Resources have been utilized from many sources that should be acknowledged: Africare and the Better U Foundation (Mali/wheat); FAO and the European Union's Food Facility Project (Nepal/ wheat); India's National Bank for Agriculture and Rural Development and the Sir Dorabji Tata Trust (India/wheat and other crops); Oxfam America and the Bill and Melinda Gates Foundation (Ethiopia/tef); the Swedish Society of Nature Conservation (Ethiopia/ planting with space); the Worldwide Fund for Nature-ICRISAT dialogue project on food, water, and environment (India/sugar); and the World Bank/IDA (India/wheat and other crops in Bihar).

\section{Author details}

${ }^{1}$ PRADAN, Ranchi, Jharkhand, India. ${ }^{2}$ Institute for Sustainable Development, Addis Ababa, Ethiopia. ${ }^{3}$ Agricultural Transformation Agency, Addis Ababa, Ethiopia. ${ }^{4}$ AgSri Agricultural Services Pvt. Ltd, Hyderabad, India. ${ }^{5}$ Nepal Agricultural Research Council, Banke, Nepal. ${ }^{6}$ CEDAC, Phnom Penh, Cambodia. ${ }^{7}$ People's Science Institute, Dehradun, India. ${ }^{8}$ FarmMore Pvt. Co. Ltd, Lahore, Pakistan. ${ }^{9}$ SRI International Network and Resources Center (SRI-Rice), Cornell University, Ithaca, NY, USA. ${ }^{10}$ PRAN-PRADAN, Gaya, Bihar, India.

Received: 16 October 2013 Accepted: 23 January 2014 Published: 25 February 2014

\section{References}

1. Royal Society: Reaping the Benefits: Science and the Sustainable Intensification of Global Agriculture. London: The Royal Society; 2009.

2. Montpellier Panel: Sustainable Intensification: A New Paradigm for African Intensification. London: Imperial College; 2013.

3. World Bank: Agricultural Investment Sourcebook, Module 4: Investments in Sustainable Agricultural Intensification. DC: Washington; 2006.

4. IFAD/UNEP: Smallholders, Food Security and the Environment. Rome: International Fund for Agricultural Development, and Nairobi: United Nations Environment Program; 2013.

5. European Parliament: Agricultural Technologies for Developing Countries, Report of project for the EU's Science and Technology Options Assessment project (IP/A/STOA/FWC/2005-28/SC42). European Parliament: Brussels; 2009.

6. FAO: Save and Grow: A Policymaker's Guide to the Sustainable Intensification of Smallholder Crop Production. Rome: UN Food and Agriculture Organization; 2011.

7. IAASTD: Agriculture at a Crossroads: Synthesis Report of the International Assessment of Agricultural Knowledge, Science and Technology for Development. Washington, DC: Island Press; 2009.

8. Altieri MA: Agroecology: The Science of Sustainable Agriculture. Boulder, CO: Westview Press; 1995.
9. Gliessman SR: Agroecology: The Ecology of Sustainable Food Systems. Boca Raton, FL: CRC Press; 2007.

10. Uphoff N: ed: Agroecological Innovations: Increasing Food Production with Participatory Development. London: Earthscan; 2002.

11. Dash TK, Pal A: Growing Crops with SRI Principles. Bhubaneswar: SRI Secretariat and Sir Dorabji Tata Trust; 2011 [http://sdtt-sri.org/wp-content/ themes/SDTT-SRI/Document/output.pdf].

12. Araya H, Edwards S, Asmelash A, Legasse H, Zibelo GH, Mohammed E, Misgina S: SCl: Planting with Space. Farming Matters 2013, 29:35-37.

13. Watershed Organisation Trust: SCl: System of Crop Intensification - A Step towards Climate-Resistant Agriculture. Pune: WOTR; 2013.

14. Agricultural Transformation Agency: Results of 2012 New Tef Technology Demonstration Trials. Addis Ababa: ATA and Ethiopian Institute for Agricultural Research, Ministry of Agriculture, Federal Democratic Republic of Ethiopia; 2013.

15. Behera D, Chaudhury AK, Vutukutu VK, Gupta A, Machiraju S, Shah P: Enhancing Agricultural Livelihoods through Community Institutions in Bihar, India, South Asia Livelihoods Learning Series. New Delhi: World Bank, and Patna: JEEVIKA; 2013 [http://documents.worldbank.org/curated/en/2013/01/ 17517688/enhancing-agricultural-livelihoods-through-communityinstitutions-bihar-india].

16. World Bank Institute: System of Rice Intensification (SRI): Achieving more with less, a new way of cultivating rice. [http://info.worldbank.org/etools/docs/ library/245848/].

17. Stoop WA, Uphoff N, Kassam A: A review of agricultural research issues raised by the system of rice intensification (SRI) from Madagascar: Opportunities for improving farming systems for resource-poor farmers. Agric Systems 2002, 71:249-274.

18. Uphoff N, Randriamiharisoa R: Possibilities for reducing water use in irrigated rice production through the Madagascar System of Rice Intensification (SRI). In Water-Wise Rice Production. Edited by Bouman BA. Los Baños, Philippines: International Rice Research Institute; 2002:71-87.

19. Uphoff N: Supporting food security in the 21 st century through resource-conserving increases in agricultural production. Agric \& Food Security 2012, 1:18.

20. Uphoff N: Agroecological opportunities to help 'climate-proof' agriculture while raising productivity in the 21 st century. In Sustainable Soil Productivity in Response to Global Climate Change. Edited by Sauer TS, Norman JM, Sivakumar MVK. Chichester: JW Wiley; 2011:87-102.

21. Uphoff N: Raising smallholder food crop yields with climate-smart agroecological practices. Washington: Booklet supplement for World Bank Institute seminar; 2012 [http://sri.ciifad.cornell.edu/aboutsri/othercrops/ Other_Crops_Brochure_Uphoff101012.pdf].

22. SRI-Rice: The System of Crop Intensification: Agroecological Innovations to Improve Agricultural Production, Food Security, and Resilience to Climate Change, SRI International Network and Resources Center. Ithaca, NY: Cornell University [http://sri.ciifad.cornell.edu/aboutsri/othercrops/ SClmonograph_SRIRice2014.pdf].

23. Barah BC, Mishra S, Kumar R, Narendranath, Singh S: Scientific validation of principles of the System of Wheat Intensification, Draft paper prepared for Indian Agricultural Research Institute. New Delhi; 2013. summarizing results from 2 years of on-station SWI trials at IARI.

24. Berhe T, Gebretsadik Z, Edwards S, Araya H: Boosting tef productivity using improved agronomic practices and appropriate fertilizer. In Achievements and Prospects of Tef Improvement. Edited by Assefa H, Chanyalew S, Tadele Z. Addis Ababa: Ethiopian Institute of Agricultural Research, and Bern: Institute of Plant Sciences; 2013:133-140.

25. The Green Foundation: Guli Vidhana: A Farmer Innovation for Bumper Crop. Bangalore: The Green Foundation; 2006.

26. PRADAN: Cultivating Finger Millet with SRI Principles: A Training Manual. Ranchi: PRADAN and Sir Dorabji Tata Trust; 2012. English translation published by SRI-Rice. [http://sri.ciifad.cornell.edu/aboutsri/othercrops/fingermillet/ In_SRMI_Pradan.pdf].

27. Prasad A: Going against the grain: The system of rice intensification is now being adapted to wheat - with similar good results. New Delhi: Outlook Business; 2008:54-55.

28. Chopra R, Sen D: Golden wheat becomes more golden: Extending SRI to wheat. LEISA-India 2013, 15:30-32.

29. PRADAN: Cultivating Wheat with SRI Principles: A Training Manual. Gaya: PRADAN; 2012 [http://sri.ciifad.cornell.edu/aboutsri/othercrops/wheat/ In_SWI_Pradan.pdf]. 
30. Raol RK: SWI Experience in Bihar, Report for Aga Khan Rural Support Programme-India. New Delhi: AKRSP-India; 2012.

31. Styger $E: 60$ farmers evaluate the System of Rice Intensification in Timbuktu 2008/09. [http://www.erikastyger.com/SRI_Timbuktu_Blog/ SRI_Timbuktu_Blog.html].

32. Styger E, Aboubacrine G, Attaher MA, Uphoff N: The system of rice intensification as a sustainable agricultural innovation: Introducing, adapting and scaling up SRI in the Timbuktu region of Mali. Intl J Agric Sustainability 2011, 9:67-75.

33. Styger $\mathrm{E}$, Ibrahim $\mathrm{H}$ : The System of Wheat Intensification: First time testing by farmers in Goundam and Dire, Timbuktu, Mali, 2009. Bamako: Africare Mali; 2008 [http://ciifad.cornell.edu/sri/countries/mali/MaliSWlrpt071309.pdf].

34. Styger E: Scaling up SRI in Goundam and Dire Circles of Timbuktu, 2009/2010 Africare Mali: Bamako; 2010:23-26. [http://sri.ciifad.cornell.edu/countries/ mali/MaliTimbuktu_2009_2010.pdf].

35. Khadka RB, Raut P: System of Wheat Intensification (SWI): A new concept on low-input technology for increasing wheat yield in marginal land. Paper for European Union Food Facility Project: Lalitpur; 2012.

36. Adhikari D: A Sharing on System of Wheat Intensification (SWI) in Sindhuli, Nepal. Sindhuli, Nepal: Report of the District Agricultural Development Office; 2012 [http://www.slideshare.net/SRI.CORNELL/12107-swi-sindhuli-nepal].

37. Zhang WJ, Liu J: System of Wheat-Rice Intensification (SWRI) with Conservation Agriculture in Jiangsu Province, China. Beijing: Institute of Agro-ecology and Farming Systems, China Academy of Agricultural Sciences; 2008 [http://sri. ciifad.cornell.edu/countries/china/chSWRIwheatriceCAAS08.pdf].

38. Zhang WJ, Lu M: Innovational Rice-Wheat Cropping System for Higher Yield with Lower Emissions in China, Based on the Concepts of SRI. Beijing: Institute of Crop Sciences, China Academy of Agricultural Sciences; 2010 [http://sri. ciifad.cornell.edu/countries/china/ChinaSWRI_Zhang2010.pdf].

39. ICRISAT/MWF: Sustainable Sugarcane Initiative: Improving Sugarcane Cultivation in India - A Training Manual, Dialogue Project on Food, Water and Environment. Hyderabad: Intl. Crop Research Institute for the Semi-Arid Tropics, and World Wide Fund for Nature; 2009 [http://www.indiawaterportal.org/sites/ indiawaterportal.org/files/SSI\%20Training\%20Manual_WWF_ICRISAT_2009.pdf].

40. AgSRI: SSI: Sustainable Sugarcane Initiative - Producing' More with Less. Hyderabad: AgSri and National Bank for Agriculture and Rural Development; 2012 [http://www.agsri.com/images/documents/ssi/ssi_manual_2012.pdf].

41. PRADAN: Cultivating Rapeseed/Mustard with SRI Principles: A Training Manual. Gaya: PRADAN; 2012. English translation published by SRI-Rice. [http://sri. ciifad.cornell.edu/aboutsri/othercrops/otherSCI/In_SMlmustard_Pradan.pdf].

42. Baskaran P: STI: The System of Turmeric Intensification - An Innovative Method for Cultivation of Turmeric (Cucurma longa). Thambal: Thambal SRI Farmers' Association; 2012 [http://sri.ciifad.cornell.edu/aboutsri/othercrops/otherSCl/ InTN_STI_Baskaran092712.pdf].

43. Daisy M, Thavaprakash N, Velayudam K, Divya V: Effect of system of crop intensification $(\mathrm{SCl})$ practices on growth, yield attributes and yield of castor hybrid YRCH1. J Adv Life Sci 2013, 6:366-374.

44. Araya H, Edwards S: Planting with Space. Addis Ababa: Institute for Sustainable Development; 2011 [http://www.isd.org.et/Publications/planting \%20with\%20space.pdf].

45. Lim S: Experiences in Multi-Purpose Farm Development: Raising Household Incomes in Cambodia by Utilizing Productivity Gains from the System of Rice Intensification. Phnom Penh: Cambodian Center for Study and Development of Agriculture; 2007 [http://sri.ciifad.cornell.edu/countries/ cambodia/cambSidMPREng.pdf].

46. Sharif A: Technical adaptations for mechanized SRI production to achieve water saving and increased profitability in Punjab, Pakistan. Paddy \& Water Envir 2011, 9:111-119.

47. ILEIA: SRI: Much more than more rice. Farming Matters 2013, 29:1.

\section{doi:10.1186/2048-7010-3-4}

Cite this article as: Abraham et al:: The system of crop intensification: reports from the field on improving agricultural production, food security, and resilience to climate change for multiple crops. Agriculture \& Food Security 2014 3:4.

\section{Submit your next manuscript to BioMed Central and take full advantage of:}

- Convenient online submission

- Thorough peer review

- No space constraints or color figure charges

- Immediate publication on acceptance

- Inclusion in PubMed, CAS, Scopus and Google Scholar

- Research which is freely available for redistribution

Submit your manuscript at www.biomedcentral.com/submit
C BioMed Central 